\title{
Agnieszka Mikucka-Kowalczyk
}

Uniwersytet Ekonomiczny we Wrocławiu

e-mail: agnieszka.mikucka-kowalczyk@ue.wroc.pl

\section{SPOLECZNA ODPOWIEDZIALNOŚĆ PRZEDSIĘBIORSTW DZIALAJĄCYCH NA RYNKACH MIĘDZYNARODOWYCH NA PRZYKŁADZIE KGHM POLSKA MIEDŹ SA}

\section{SOCIAL RESPONSIBILITY OF COMPANIES OPERATING AT INTERNATIONAL MARKETS ON THE EXAMPLE OF KGHM}

DOI: $10.15611 / \mathrm{e} 21.2017 .1 .03$

JEL Classification: A1, F2, M21, O15

Streszczenie: Przedsiębiorstwa w XXI wieku muszą sprostać zmianom zasad prowadzenia biznesu wynikającym z globalizacji gospodarki. Poszukują zatem rozwiązań umożliwiających funkcjonowanie w coraz trudniejszym i dynamicznie zmieniającym się otoczeniu. Jednocześnie pojawienie się i wzrost znaczenia działań społecznie odpowiedzialnych wywołuje potrzebę bliższego przyjrzenia się ich skutkom w działaniach na rzecz „ludzkiej twarzy globalizacji”. KGHM to firma globalna, otwarta na nowe kierunki rozwoju. Obecność w wielu krajach, na różnych kontynentach, stwarza spółce możliwość wpływania na dobrostan społeczności, regionów i krajów, a więc na realizację postulatu globalizacji etycznej i sprawiedliwej.

Słowa kluczowe: społeczna odpowiedzialność przedsiębiorstwa, strategia CSR, globalizacja, przedsiębiorstwo międzynarodowe, humanizacja procesu globalizacji.

Summary: Companies from the twenty-first century have to comply with altering rules for business activity resulting from globalising economy. Thus, they search for the solutions enabling their operation in more and more difficult and dynamically changing environment. At the same time, the occurrence and the increased importance of socially responsible actions demand closer insight into the effects of activities oriented on the "human face of globalisation". KGHM is a global company and is opened for new ways of development. Its presence in many countries, on various continents, makes it possible the company influences the wellbeing of societies, regions and even countries, thus the realisation of the demand of ethical and equitable globalisation.

Keywords: Corporate Social Responsibility, CSR strategy, globalization, international company, humanization of globalization process. 


\section{Wstęp}

Pojawienie się i wzrost znaczenia społecznej odpowiedzialności przedsiębiorstw (Corporate Social Responsibility - CSR) międzynarodowych, takich jak KGHM Polska Miedź SA, wywołuje potrzebę bliższego przyjrzenia się konsekwencjom, jakie ona wywołuje zarówno w działalności samych przedsiębiorstw, jak i w środowisku międzynarodowym.

Koncepcja społecznej odpowiedzialności przedsiębiorstwa ma charakter strategiczny i dynamiczny. Działania organizacji społecznie odpowiedzialnej bazują zatem na ciągłym doskonaleniu oraz stałej współpracy ze wszystkimi interesariuszami. Istotną cechą tej koncepcji jest jej interdyscyplinarność, a nawet transdyscyplinarność, pokazująca konieczność integrowania i konwersji wiedzy z różnych dziedzin nauki, a także praktyki gospodarczej, w szczególności w dobie globalizacji [Rok 2013, s. 423].

Postępujące umiędzynarodowienie działalności gospodarczej, które coraz bardziej scala gospodarki narodowe, prowadzi do powstania jednolitej gospodarki światowej, tworzy wiele różnorodnych i złożonych zjawisk oraz procesów. Wobec tego istotną rolę odgrywają korporacje międzynarodowe, jak KGHM Polska Miedź SA, a rozwój technologii, postępu technicznego i sieciowych powiązań o charakterze produkcyjno-handlowym, implikuje również w sferze społecznej [Micał 2008, s. 169]. Wobec tego warto spojrzeć na rolę biznesu w społeczeństwie, a w szczególności na kształtowanie się różnych aspektów konkurencyjności naszej gospodarki na rynkach nie tylko lokalnych, ale także europejskim i globalnym [Rok 2013, s. 431].

KGHM Polska Miedź SA jest nowoczesnym, globalnym przedsiębiorstwem z ponad 50-letnią tradycją. Powstało w 1961 roku, w wyniku przekształcenia przedsiębiorstwa państwowego pod nazwą Kombinat Górniczo-Hutniczy Miedzi, na podstawie art. 5 Ustawy z dnia 13 lipca 1990 r. o prywatyzacji przedsiębiorstw państwowych (Dz.U. nr 51, poz. 298 z późń. zm.). W 1991 roku przekształcono je w spółkę akcyjną, a od 1997 roku akcje spółki notowane są na Giełdzie Papierów Wartościowych w Warszawie. KGHM jest jedynym w Polsce producentem miedzi z surowców pierwotnych. Złoża rudy miedzi, odkryte przed ponad półwieczem na terenie aktualnego Legnicko-Głogowskiego Okręgu Miedziowego, należą do głównych bogactw naturalnych kraju. Spółka ma własną zintegrowaną strukturę produkcyjną, w której skład wchodzą trzy kopalnie (Zakłady Górnicze „Lubin”, Zakłady Górnicze „Polkowice - Sieroszowice”, Zakłady Górnicze „Rudna), trzy huty miedzi (Huta Miedzi „Głogów”, Huta Miedzi „Legnica”, Huta Miedzi „Cedynia”) oraz oddziały wspomagające działalność podstawową (Zakłady Wzbogacania Rud, Zakład Hydrotechniczny, Centrala, Jednostka Ratownictwa Górniczo-Hutniczego, Centralny Ośrodek Przetwarzania Informacji). W Oddziałach KGHM zatrudnionych jest ponad 18500 pracowników, a w spółkach zależnych, które tworzą Grupę Kapitałową KGHM, zatrudnia się ponad 12000 osób. Ponadto Grupa KGHM ma projekty górnicze na trzech kontynentach: kopalnie w Kanadzie, USA i Chile, oraz pięć projektów w fazie 
inwestycyjnej i przedinwestycyjnej, jak choćby Afton Ajax i Victoria w Kanadzie oraz Malmbjerg na Grenlandii [Człowiek wśród żywiołów 2014, s. 2-4].

Celem opracowania jest przybliżenie koncepcji społecznej odpowiedzialności przedsiębiorstw oraz możliwości zmiany aktualnego modelu globalizacji przez realizację działań społecznie odpowiedzialnych przedsiębiorstw międzynarodowych na przykładzie KGHM Polska Miedź SA.

\section{Charakterystyka koncepcji społecznej odpowiedzialności}

Społeczna odpowiedzialność przedsiębiorstw jest względnie nową, jednakże cieszącą się coraz większą popularnością koncepcją działania firm. Inspiruje ona przedstawicieli świata biznesu do poszukiwania nowego, kreatywnego prowadzenia działalności z poszanowaniem różnych grup interesariuszy oraz środowiska naturalnego.

Koncepcja CSR wskazuje zatem z jednej strony na konieczność ponoszenia konsekwencji działań przedsiębiorstwa, natomiast z drugiej - na konieczność odpowiadania na potrzeby określonych ludzi, grup czy organizacji społecznych, które stanowią otoczenie przedsiębiorstwa [Adamczyk 2009, s. 53]. Na potrzeby niniejszego opracowania przez społeczną odpowiedzialność przedsiębiorstwa należy rozumieć dobrowolne, wykraczające poza minimalne wymogi prawne, uwzględnianie przez przedsiębiorstwo w działalności komercyjnej i stosunkach z zainteresowanymi podmiotami problematyki zarówno społecznej, jak i środowiskowej. Wynika z tego konieczność odpowiedzialnego i etycznego postępowania biznesu wobec grup społecznych, na które oddziałuje z poszanowaniem środowiska przyrodniczego. Inaczej mówiąc, koncepcja CSR odnosi się do zarządzania przedsiębiorstwem polegającego na w pełni świadomym, zrównoważonym działaniu, zorientowanym nie tylko na zysk finansowy, ale także na potrzeby i wymagania interesów społecznych i ekologicznych w otoczeniu firmy [Kocoń 2014, s. 50].

Aby skutecznie zarządzać społecznym działaniem, przedsiębiorstwo musi wiedzieć, wobec kogo jest odpowiedzialne, społeczeństwo bowiem składa się z różnych grup, a zagrożenia i korzyści związane z działalnością przedsiębiorstwa mogą dotyczyć tylko niektórych z nich [Rybak 2011, s. 43]. Z pomocą w tej kwestii przychodzi teoria stakeholders, na której opiera się społeczna odpowiedzialność przedsiębiorstw, zakładająca uwzględnianie przez przedsiębiorstwo interesów różnych grup interesariuszy [Nakonieczna 2008, s. 55].

Za stakeholders przyjmuje się te podmioty i grupy osób spełniające następujące kryteria [Mendel 2002, s. 18]:

- wysuwają żądania wobec firmy (niezależnie od natury tych żądań),

- mogą wyegzekwować te żądania lub mają taką możliwość,

- mają warunkową bądź bezwarunkową chęć wykorzystania swojej siły wpływu na proces decyzyjny przedsiębiorstwa w celu zaspokojenia swych żądań.

Kontekstowość pojęcia odpowiedzialności społecznej powoduje, że nie jest możliwe wyznaczenie bezwzględnego poziomu odpowiedzialności społecznej [Kru- 
kowska 2012, s. 183]. Wynika to z tego, iż społeczna odpowiedzialność przedsiębiorstwa oznacza, z jednej strony, konieczność ponoszenia konsekwencji działań przedsiębiorstwa, z drugiej zaś - konieczność odpowiadania na potrzeby określonych ludzi, grup czy organizacji społecznych stanowiących otoczenie przedsiębiorstwa. Wobec tego można wyróżnić wiele obszarów społecznej odpowiedzialności przedsiębiorstw, np. ekonomiczny, socjologiczny, ekologiczny, etyczny, prawny i filantropijny (rys. 1) [Adamczyk 2009, s. 53].

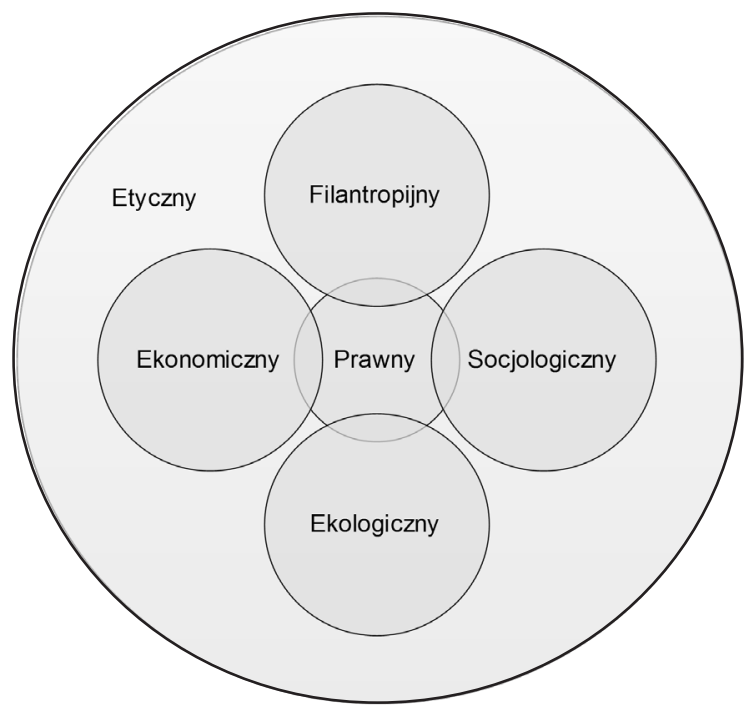

Rys. 1. Podstawowe obszary społecznej odpowiedzialności przedsiębiorstwa

Źródło: [Adamczyk 2009, s. 53].

Należy także wskazać na to, iż społeczna odpowiedzialność przedsiębiorstwa może być jednym z istotnych wymiarów efektywnej strategii. Ciągły rozwój, a także wcześniejsze zrealizowanie kluczowych projektów dotychczasowej strategii sprawiły, że w styczniu 2015 roku zatwierdzono w KGHM nową Strategię na lata 2015-2020 z perspektywą do 2040 roku. Jej podstawowym celem jest osiągnięcie łącznie rocznych zdolności produkcyjnych na poziomie ponad $1 \mathrm{mln}$ ton miedzi ekwiwalentnej oraz kontynuacja stałej poprawy efektywności prowadzonej działalności wydobywczej [Raport zintegrowany KGHM Polska Miedź SA... 2015, s. 97-103]. Natomiast Strategia społecznej odpowiedzialności biznesu na lata 2012-2018, przyjęta w czerwcu 2012 roku, stanowi integralną część globalnej Strategii biznesowej KGHM zatwierdzonej w styczniu 2015 roku. Celem głównym strategii CSR KGHM jest wzmacnianie pozycji stabilnego, rozwijającego się, globalnego lidera, dbającego o dobro wspólne. Strategiczne kierunki społecznej odpowiedzialności spółki do roku 2020 to [Strategia społecznej odpowiedzialności biznesu... 2015, s. 1-7]: 
- globalizacja obszaru CSR,

- doskonalenie współpracy ze społecznościami lokalnymi,

- ugruntowanie pozycji zaufanego i stabilnego partnera biznesowego,

- wypracowanie i utrzymanie pozycji odpowiedzialnego pracodawcy,

- budowa wizerunku spółki przyjaznej środowisku.

Takie sformułowanie strategii CSR wskazuje iż, społeczna odpowiedzialność to wyznacznik wszystkich działań spółki. Priorytetem jest troska o dobro wspólne i zrównoważoną gospodarkę zasobami naturalnymi. Nadrzędny cel to równowaga między rentownością a interesem społecznym otoczenia, w którym KGHM prowadzi działalność biznesową [http://www.kghm.com]. Ponadto spółka ma na względzie to, że działania z zakresu społecznej odpowiedzialności przedsiębiorstw, aby mogły przynieść wymierne efekty zarówno firmie, jak i jej interesariuszom, nie mogą się sprowadzać do jednorazowych akcji, które nie są powiązane ze strategią biznesową. W obszarze społecznego zaangażowania KGHM nastąpiło przejście do fazy mającej na celu włączenie polityki CSR do długofalowej strategii.

\section{Problemy globalne istotne $\mathrm{z}$ punktu widzenia CSR}

Globalizację najczęściej definiuje się jako procesy integracyjne w skali całego świata. Stanowi ona zatem zbiór wielokierunkowych i wielopłaszczyznowych procesów dokonujących się w dziedzinie gospodarki, handlu międzynarodowego, światowego rynku i masowego komunikowania. Globalizacja w dzisiejszych czasach odnosi się do zjawiska interakcji milionów ludzi na całym świecie, nie ma przy tym końca, jest bowiem zbiorem procesów, których nie można zatrzymać ani poddać kontroli [Borkowski (red.) 2003, s. 11-12].

Globalizację można także rozumieć jako poszerzanie, zwielokrotnienie, przyspieszenie i wzrastający wpływ wzajemnych powiązań w skali światowej [Held, McGrew 2001, s. 324]. Inaczej mówiąc, jest to intensyfikacja ogólnoświatowych relacji o charakterze społecznym, które scalają oddalone od siebie miejsca w taki sposób, iż lokalne wydarzenia są kształtowane przez wydarzenia pojawiające się w innych, oddalonych miejscach i vice versa [Giddens 2000, s. 64]. Istota procesów globalizacji polega zatem na przechodzeniu od lokalnych aż do światowych w skali globalnej interakcji w następującej sekwencji [Haliżak 2006, s. 300]:

- interakcje o charakterze lokalnym w danym kraju,

- interakcje o zasięgu krajowym - w skali całego kraju,

- interakcje między krajami,

- interakcje transgraniczne o charakterze krajowym,

- interakcje międzynarodowe regionalne,

- interakcje globalne, czyli takie, które obejmują cały glob ze wszystkimi krajami lub ich większością.

Globalizacja przebiega w wielu wymiarach, ścieżkach czy obszarach. Można wyodrębnić trzy najbardziej widoczne jej wymiary: gospodarczy, polityczny i kultu- 
rowy. Jednakże należy wskazać, iż procesy omawianego zjawiska nie zachodzą w sposób równomierny i z podobnym natężeniem, a i samo zainteresowanie jego wymiarami ma dynamiczny charakter. Najdłużej proces globalizacji obserwowany jest w płaszczyźnie ekonomicznej, jako rosnąca współzależność gospodarcza, w której jest poniekąd najbardziej rozwinięty [Nakonieczna 2008, s. 196-197]. Prowadzi to do zwiększenia integracji w organizacji produkcji, dystrybucji i konsumpcji towarów, co w konsekwencji prowadzi do zmian w gospodarce światowej, czyniąc ją przede wszystkim kapitalistyczną i coraz bardziej współzależną [Kuźmińska, Sawicki 2009, s. 230-231].

Natomiast globalizację gospodarczą, jako przedmiot badań naukowych, należy pojmować z punktu widzenia pozytywnego i normatywnego. Badania o charakterze pozytywnym polegają na opisie i wyjaśnianiu zjawisk ekonomicznych, które mają globalny zakres, takich jak funkcjonowanie rynków międzynarodowych i globalnych przedsiębiorstw, jakim jest niewątpliwie KGHM. W poszczególnych fazach globalizacji pojawiają się nowe aspekty działań gospodarczych, inne powiązania i zależności, a także nowe formy współpracy. Ponadto badania tego rodzaju dokonują względnie neutralnego opisu rynków i przedsiębiorstw za pomocą pojęć ryzyka, kosztów i korzyści ekonomicznych. Natomiast pojmowanie globalizacji z punktu widzenia normatywnego polega na ocenie różnorodnych działań globalnych i niekiedy na budowaniu wizji idealnej globalizacji [Klimczak 2008, s. 75].

W najmniejszym stopniu proces globalizacji dotyczy wymiaru politycznego przybierającego dość nieokreślone kształty. Jednym z czynników, który warto wymienić, jest problem opanowania i efektywnego kierowania tymi procesami, albowiem przebiegają one w sposób niekontrolowany, co doprowadziło do powstania chaosu globalnego przejawiającego się przede wszystkim w przewadze efektów negatywnych nad pozytywnymi [Nakonieczna 2008, s. 197]. Ponadto z punktu widzenia wymiaru kulturowego globalizacja nie byłaby możliwa, gdyby nie intensywny rozwój technologii komunikacyjnych. Wynika to z tego, iż umożliwiają one dyfuzję i amalgamację kulturową, co wywołuje konflikty o charakterze kulturowym. Można zatem zaobserwować globalizację komunikowania rozumianego w szeroki sposób, czyli zarówno transportu i przemieszczania się ludzi, jak i komunikację rozumianą jako wymiana informacji [Kuźmińska, Sawicki 2009, s. 231].

Obszary zainteresowania CSR, takie jak: społeczny, systemowy, rynkowy, ekologiczny oraz publiczny, stanowią przedmiot rosnącego zaniepokojenia, a zarazem coraz większej troski w erze gospodarczej globalizacji. Wobec tego największe przedsiębiorstwa międzynarodowe, np. KGHM, informując o swoich działaniach w wymiarze CSR, wskazują na takie obszary, jak [Janeczek, Janeczek 2014, s. 178]:

- środowisko naturalne,

- zrównoważony rozwój,

- firma w społeczeństwie,

- działalność charytatywna,

- przejrzystość w biznesie, 
Agnieszka Mikucka-Kowalczyk

- prawa człowieka i prawa pracownicze,

- edukacja i nauka.

Problemy globalne istotne z punktu widzenia koncepcji CSR wymagałyby kompleksowej analizy dotychczasowych efektów globalizacji, uwzględniając poziom mikro, mezo, makro i globalny. Należałoby je także rozpatrywać w wymiarze społecznym, politycznym, technologicznym, ekonomicznym, kulturalnym itd. (rys. 2). Ponadto konieczne byłoby uwzględnienie również perspektywy długiego i krótkiego okresu oraz bezpośredniego i pośredniego charakteru efektów globalizacji [Rymarczyk 2012, s. 43].

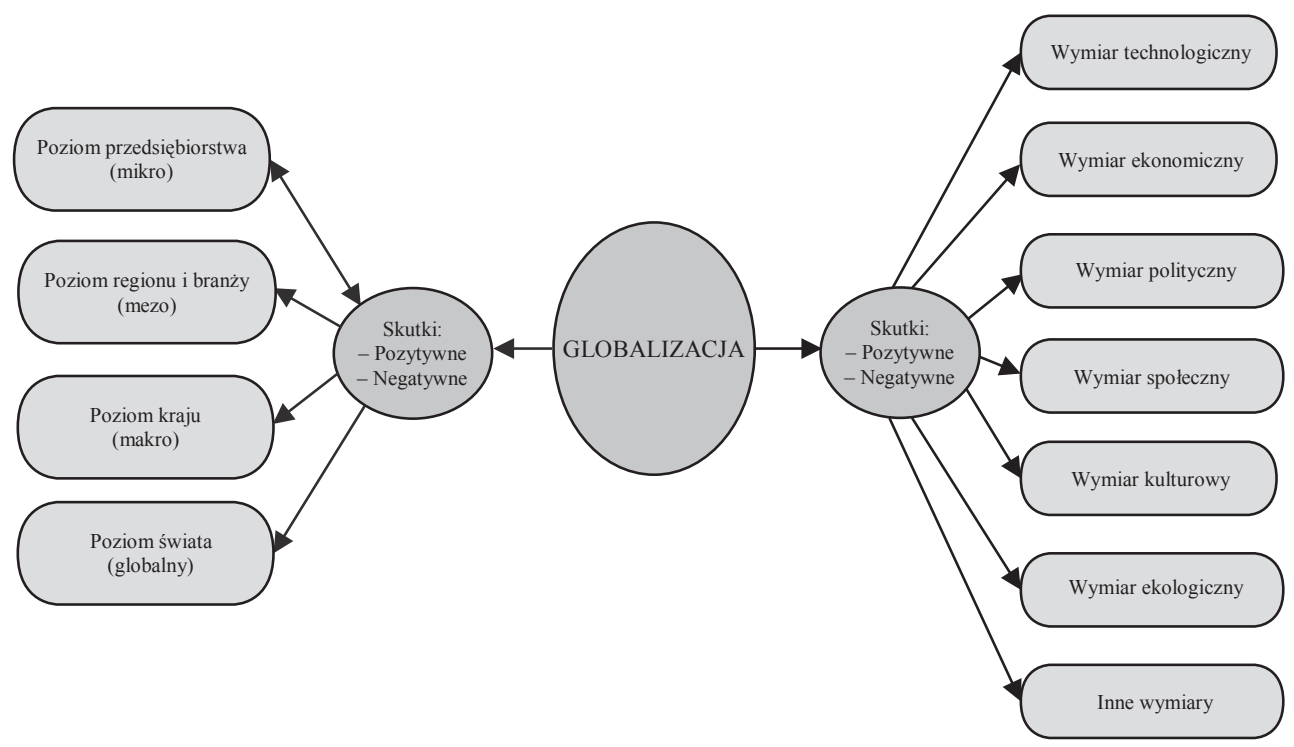

Rys. 2. Poziomy i wymiary globalizacji

Źródło: [Rymarczyk 2012, s. 44].

W tabeli 1 zaprezentowano wybrane problemy globalne ważne dla KGHM z perspektywy koncepcji CSR, dotyczące sfery zarówno ekonomicznej, jak i społecznej.

Korzyści dla KGHM z globalizacji wynikają z otwarcia rynków narodowych, uwolnienia rynków walutowych, liberalizacji regulacji dotyczących inwestycji bezpośrednich. Jednakże korzystanie z wolnych rynków może spowodować pojawienie się kosztów dla innych uczestników rynków. Przykładowo wzrost bezpośrednich inwestycji zagranicznych służy często do blokowania wejścia na rynki. Z kolei mobilność kapitału spekulacyjnego może być przyczyną niestabilności walut narodowych i narodowych systemów finansowych. Za przyczyny rosnących kosztów współczesnej globalizacji uważa się także niedostateczny rozwój globalnych rynków oraz niedoskonałą wiedzę i informację. Wobec tego, aby ograniczyć szkody 
Tabela 1. Przegląd problemów o charakterze globalnym, dotyczących sfery ekonomicznej i społecznej

\begin{tabular}{|c|c|c|}
\hline \multicolumn{2}{|r|}{ Problemy globalne } & Oczekiwania względem świata gospodarczego \\
\hline \multirow{2}{*}{ 空 } & sprawy polityczne & $\begin{array}{l}\text { - osiąganie celów milenijnych } \\
\text { - publiczne/prywatne partnerstwo }\end{array}$ \\
\hline & $\begin{array}{l}\text { konflikty i sytuacje } \\
\text { po konflikcie }\end{array}$ & - odpowiedzialne zaopatrzenie i nadzór nad zaopatrzeniem \\
\hline \multirow{4}{*}{$\begin{array}{l}\text { Ñ } \\
\frac{0}{8} \\
\text { के }\end{array}$} & $\begin{array}{l}\text { ubóstwo } \\
\text { i dysproporcje } \\
\text { społeczne }\end{array}$ & $\begin{array}{l}\text { - tworzenie bezpiecznych miejsc pracy } \\
\text { - dostarczanie żywności, zakwaterowania, opieki zdrowotnej, edukacji } \\
\text { i szkoleń } \\
\text { - udzielanie pożyczek i małych kredytów }\end{array}$ \\
\hline & edukacja & $\begin{array}{l}\text { - dostęp do monitoringu i szkoleń, rozwój umiejętności i pewności } \\
\text { siebie }\end{array}$ \\
\hline & zdrowie & $\begin{array}{l}\text { - dostępność i rozwój infrastruktury wspierającej dostęp do opieki } \\
\text { zdrowotnej } \\
\text { - rozwój przemysłu farmaceutycznego i dystrybucja leków } \\
\text { - działania prewencyjne i profilaktyka zdrowotna } \\
\text { - wprowadzanie programów ochrony zdrowotnej i bezpieczeństwa }\end{array}$ \\
\hline & trendy demograficzne & - planowanie rodziny i edukacja \\
\hline \multirow{3}{*}{ 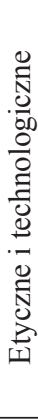 } & technologia - Internet & $\begin{array}{l}\text { - dostęp do nowoczesnych narzędzi teleinformatycznych } \\
\text { - rozwój i szkolenia umiejętności, pozwalających na efektywne } \\
\text { wykorzystanie nowoczesnych technologii }\end{array}$ \\
\hline & $\begin{array}{l}\text { nadzór - korupcja } \\
\text { i przestępstwa }\end{array}$ & $\begin{array}{l}\text { - promocja transparentności, jasnego i czytelnego nadzoru } \\
\text { - działanie zgodne z prawem } \\
\text { - zmienianie i usprawnianie systemów prawnych } \\
\end{array}$ \\
\hline & $\begin{array}{l}\text { etyka indywidualna } \\
\text { a etyka globalna }\end{array}$ & $\begin{array}{l}\text { - działalność oparta na angażowaniu się we wspólnoty lokalne, } \\
\text { myślenie lokalne, promocja lokalnych produktów i usług } \\
\text { - zaangażowanie pracowników w społeczność lokalną } \\
\text { - rozwój partnerski }\end{array}$ \\
\hline \multirow{3}{*}{ 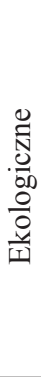 } & zmiany klimatyczne & $\begin{array}{l}\text { - obniżanie stopnia emisji dwutlenku węgla } \\
\text { - większa wydajność w korzystaniu ze źródeł energii lub } \\
\text { wykorzystywanie źródeł energii odnawialnej }\end{array}$ \\
\hline & wodne problemy & $\begin{array}{l}\text { - budowa oczyszczalni ścieków i lepsze wykorzystywanie wód } \\
\text { - ograniczenie ilości odpadów i recykling } \\
\text { - tworzenie produktów, które wykorzystują mniej materiałów } \\
\text { i oszczędność surowców }\end{array}$ \\
\hline & biotechnologia & $\begin{array}{l}\text { - zbieranie informacji } \\
\text { - wdrażanie środków ochronnych i zapobiegawczych }\end{array}$ \\
\hline $\begin{array}{l}0 \\
\frac{0}{0} \\
\frac{0}{0} \\
\frac{\overrightarrow{0}}{0} \\
\mathbf{N}\end{array}$ & $\begin{array}{l}\text { zrównoważony } \\
\text { rozwój, produkcja } \\
\text { i konsumpcja } \\
\text { (odpowiedzialny } \\
\text { konsumeryzm) }\end{array}$ & $\begin{array}{l}\text { - informowanie o korzyściach zrównoważonej produkcji } \\
\text { - wdrażanie systemów oznakowania produktów - maksymalizacja } \\
\text { użyteczności produktów i ich pochodnych } \\
\text { - korzystanie z komponentów i surowców do produktów, które } \\
\text { były wytwarzane w społecznie i ekologicznie odpowiedzialnym } \\
\text { środowisku }\end{array}$ \\
\hline
\end{tabular}

Źródło: [Janeczek, Janeczek 2014, s. 178-179]. 
Agnieszka Mikucka-Kowalczyk

i zwiększyć korzyści wynikające z globalizacji, należy określić odpowiedzialność uczestników globalnych rynków, takich jak m.in. KGHM, oraz sposób rozliczania ich z prowadzonej działalności. Rozwiązaniem tej kwestii może być instytucjonalizacja globalnych rynków i globalnych firm, oznaczająca tworzenie przez różne podmioty i na różnych poziomach takich ograniczeń wolności gospodarczych, które sprzyjają odpowiedzialności za przyjęte zobowiązania, co umożliwia wyrównywanie szans i przewidywalność [Klimczak 2008, s. 80-82].

\section{Rola i miejsce humanizacji procesu globalizacji w działaniach społecznie odpowiedzialnych w KGHM Polska Miedź SA}

Pojawienie się i wzrost znaczenia społecznej odpowiedzialności przedsiębiorstw międzynarodowych, takich jak KGHM, stwarzają potrzebę bliższego przyjrzenia się konsekwencjom ich działalności w środowisku międzynarodowym.

Misją KGHM jest rozwój globalnej grupy surowcowej tworzonej przez ludzi z pasją i kompetencjami przez realizację Strategii KGHM Polska Miedź SA na lata 2015-2020 z perspektywą do 2040 roku. Jednym z jej trzech filarów jest rozwój bazy zasobowej przez szeroki program eksploracji w Polsce i na świecie [Strategia KGHM Polska Miedź SA... 2015, s. 2]. Wobec tego, jako firma międzynarodowa, powinna ona prowadzić swoją politykę tak, aby następowało osłabienie ujemnych aspektów ekspansji handlu międzynarodowego. Musi także w coraz większym stopniu ponosić odpowiedzialność za uboczne skutki globalizacji, jak chociażby degradacja środowiska naturalnego czy przemieszczanie się ludności. Można zatem wskazać na wdrażanie polityki odpowiedzialności społecznej jako na jeden ze sposobów znajdujących zastosowanie w KGHM do łagodzenia skutków globalizacji [Janeczek, Janeczek 2014, s. 180-181].

KGHM, zgodnie z typową ewolucją przedsiębiorstw, stopniowo przechodziła następujące fazy [Borowicz 1997, s. 57-58]:

- Początkowo nastąpił rozwój w skali krajowej. Spółka wykorzystała wszystkie możliwości, aby uzyskać specyficzne korzyści. Na tym etapie nie była zainteresowana ekspansją zagraniczną, ponieważ rozmiar rynku wewnętrznego był satysfakcjonujący. W latach 1949-1954 nastąpiła reaktywacja kopalń: „Lena”, „Konrad” i „Nowy Kościół” w tzw. Starym Zagłębiu Miedziowym. Rejon ten, mimo niewielkiej produkcji, stał się miejscem, gdzie zdobywała doświadczenia znaczna część kadry górniczej, biorąca udział w budowie Polskiej Miedzi. Następnie zbudowano i uruchomiono hutę w Legnicy na potrzeby przeróbki rudy ze wspomnianego obszaru. Lata sześćdziesiąte XX wieku przyniosły powstanie Zakładów Górniczych „Lubin”, „Polkowice” i „Rudna”, a także budowę huty w Głogowie i wyprodukowanie pierwszego koncentratu. Natomiast początek lat dziewięćdziesiątych rozpoczął się powołaniem 12 września 1991 roku jednooso- 
bowej Spółki Skarbu Państwa - KGHM Polska Miedź SA. Oznaczało to wejście na drogę prywatyzacji, a także przygotowanie do samodzielnego przeprowadzania transakcji handlowych i uruchomienia biura w Londynie [http://www.kghm. com].

- Druga faza charakteryzowała się wzrostem działalności eksportowej. Spółka osiągnęła wówczas odpowiednią wielkość produkcji, a nawet uzyskała określoną jej nadwyżkę. Doprowadziło to do rozszerzenia rynku i eksportu.

- Spółka rozpoczęła przemieszczanie produkcji za granicę. Przyczyniło się to do zwiększenia dostępu do surowców. Przejawem tego było utworzenie 4 maja 2010 roku spółki joint venture z większościowym udziałem KGHM wspólnie $\mathrm{z}$ partnerem kanadyjskim Abacus Mining \& Exploration Corporation [http:// www.kghm.com].

- Następna faza to internacjonalizacja, w której KGHM stała się międzynarodową firmą dążącą do konsolidacji wszystkich operacji. Dużego znaczenia nabrała wymiana produktów finalnych i komponentów między producentami zagranicznymi a firmą macierzystą. W tej fazie nastąpił transfer kapitału, know how i zasobów ludzkich. Przejawem procesu internacjonalizacji w spółce była ewolucja stosunków własnościowych znajdująca wyraz w dywersyfikacji geograficznej kapitałui internacjonalizacja kadry kierowniczej. Następnie, 5 maja 2012 roku, nastąpiło przejęcie kanadyjskiej spółki Quadra FNX Mining Ltd. (dzisiaj KGHM International Ltd.) z siedzibą w Vancouver. Polska Miedź nabyła 100\% akcji notowanej na giełdzie w Toronto firmy. Była to największa inwestycja zagraniczna w historii zarówno KGHM, jak i Polski [http://www.kghm.com].

- Ostatnią fazą jest globalizacja. KGHM podejmuje decyzje w zakresie globalizacji wszystkich procesów. Operacje tego rodzaju są standaryzowane na obszarze dużych rynków. Ponadto na tym etapie spółka współpracuje z zagranicznymi partnerami, aby móc zmniejszyć koszty stałe. Wobec tego koncentruje się na eksploracji wokół aktualnych obszarów aktywności górniczej oraz na poszukiwaniu nisko kosztowych aktywów zlokalizowanych w stabilnych geopolitycznie lokalizacjach [Strategia KGHM Polska Miedź SA... 2015, s. 8].

Współcześnie ważnym zadaniem dla KGHM staje się znalezienie uniwersalnych zasad respektujących odrębności kulturowe i ekonomiczne krajów, w których prowadzi ona swoją działalność, m.in. Polsce, Niemczech, Kanadzie, Stanach Zjednoczonych, Chile, Grenlandii. Wobec tego spółka powinna się kierować w swoich działaniach wartościami odpowiadającymi oczekiwaniom społeczeństw, tym samym uwzględniać międzynarodowy punkt widzenia, a także stawiać czoła nowym wyzwaniom etycznym związanym z regułami prowadzenia działalności produkcyjnej i zarządzania [Sojak 2002, s. 188].

Ponadto proces samookreślania się KGHM w ramach kolejnych faz swojej ewolucji zależy od możliwości w zakresie realizacji społecznej odpowiedzialności biznesu. Ekspansja międzynarodowa prowadzona przez spółkę, tak jak każde działanie rynkowe, ukierunkowana jest na osiąganie określonych celów [Copeland, Koller, 
Murrin 1997, s. 21]. KGHM przyjęła strategię wzrostową, mającą na celu zapewnić silną pozycję wśród globalnych producentów miedzi przez poprawę efektywności, rozwój bazy zasobowej, dywersyfikację źródeł przychodu i uniezależnienie się od cen energii oraz wsparcie regionu, mając przy tym na względzie maksymalizację wartości dla akcjonariuszy. Jednakże nie można jej identyfikować tylko i wyłącznie z maksymalizacją zysków [Strategia KGHM Polska Miedź SA... 2015, s. 4-8].

Należy także zauważyć, że wartość współcześnie działającego przedsiębiorstwa tworzą nie tylko wartości: ekonomiczna, rynkowa, społeczna i ekologiczna, ale także takie elementy, jak m.in.: marka produktu, reputacja, korzyści lokalizacyjne, utalentowany zarząd i personel. Wobec tego efektywność działań podejmowanych przez KGHM w skali globalnej jest mierzona dla akcjonariuszy nie tylko klasycznie, za pomocą ekonomicznej wartości dodanej czy rynkowej wartości dodanej, ale także wskaźnikami strategicznymi, takimi jak korzyści dla pracowników, klientów czy społeczeństwa [Brilman 2002, s. 97]. Postrzegając spółkę z tej perspektywy, można twierdzić, iż będzie ona powiększać swoją wartość, generując korzyści dla pracowników, kraju, interesariuszy oraz otoczenia przez działalność na rzecz lokalnych społeczności, dbałość o środowisko naturalne i uczestnictwo w akcjach dobroczynnych [Copeland, Koller, Murrin 1997, s. 21].

Ponadto na uwagę zasługuje fakt, iż rozwój procesów globalizacji wpłynął na wzrost znaczenia społecznej odpowiedzialności przedsiębiorstw międzynarodowych, co jest poniekąd związane z zasięgiem i ze skutkami oddziaływania przedsiębiorstw, takich jak KGHM. Dotyczy to w szczególności ustalania zasad postępowania wobec wszystkich podmiotów związanych ze spółką, które często wywodzą się z różnych kręgów kulturowych [Janeczek, Janeczek 2014, s.185]. Strategia społecznej odpowiedzialności biznesu KGHM, na lata 2015-2020 przyjęta przez zarząd spółki ma charakter ogólnie obowiązujący w KGHM - nie ma w niej rozróżnienia na KGHM Polska i KGHM International. Głównym jej celem jest wzmacnianie pozycji rozwijającego się, globalnego lidera, dbającego o dobro wspólne. Opiera się ona na dodatkowych celach określonych w ramach pięciu filarów, które stanowią jej integralną część (tab. 1).

Należy zauważyć, iż jedną z reakcji na negatywne skutki globalizacji jest postulat zmiany charakteru globalizacji: z modelu, który opiera się na działaniu niewidzialnej ręki rynku, na globalizację kontrolowaną, stawiającą w centrum człowieka i sprawy społeczne [Jan Paweł II 2001]. Sam proces „oddawania globalizacji ludziom" nabrał w ostatnich latach tempa i zdobył na świecie uwagę m.in. polityków, wybitnych ekonomistów, prezesów największych przedsiębiorstw międzynarodowych [Mojsiewicz 2003, s. 554]. Powinien się on opierać na takich wartościach, jak [Nakonieczna 2005, s. 614-615]:

- poszanowanie praw człowieka - każda aktywność na poziomie międzynarodowym powinna być analizowana przede wszystkim z punktu widzenia interesów ludzi; 
Tabela 2. Cele strategiczne Strategii CSR KGHM na lata 2015-2020

\begin{tabular}{|c|c|}
\hline Filar & Cele strategiczne \\
\hline Globalizacja obszaru CSR & $\begin{array}{l}\text { - Stworzenie globalnej polityki CSR bazującej na standardach } \\
\text { zarządzania } \\
\text { - Wzmacnianie pozycji KGHM jako lidera w obszarze } \\
\text { zrównoważonego rozwoju w skali globalnej (strategia, } \\
\text { raportowanie, uczestnictwo w inicjatywach CSR) } \\
\text { - Opracowanie standardów w zakresie zrównoważonego rozwoju } \\
\text { - Standaryzacja i konsolidacja narzędzi sprawozdawczych } \\
\text { w kluczowych spółkach z Grupy KGHM } \\
\text { - Budowa międzynarodowego systemu edukacji w zakresie } \\
\text { zrównoważonego rozwoju }\end{array}$ \\
\hline $\begin{array}{l}\text { Doskonalenie współpracy } \\
\text { ze społecznościami } \\
\text { lokalnymi }\end{array}$ & $\begin{array}{l}\text { - Ustalenie zasad dialogu ze społecznościami lokalnymi i zyskanie } \\
\text { społecznego pozwolenia na prowadzenie działalności (licence to } \\
\text { operate) z wykorzystaniem najlepszych praktyk biznesowych } \\
\text { - Tworzenie programów zaangażowania społecznego na rzecz } \\
\text { lepszego zrozumienia oczekiwań interesariuszy } \\
\text { - Budowanie pozycji globalnego lidera dbającego o dobro wspólne } \\
\text { przez transparentny system dotowania i sponsorowania inicjatyw na } \\
\text { podstawie wartości KGHM } \\
\text { - Wspieranie kluczowych procesów inwestycyjnych na wszystkich } \\
\text { etapach ich rozwoju }\end{array}$ \\
\hline $\begin{array}{l}\text { Ugruntowanie pozycji } \\
\text { zaufanego i stabilnego } \\
\text { partnera biznesowego }\end{array}$ & $\begin{array}{l}\text { - Uzyskanie pozycji inwestora z wyboru dzięki przestrzeganiu zasad } \\
\text { zrównoważonego rozwoju } \\
\text { - Respektowanie praw człowieka i branie pod uwagę oczekiwań } \\
\text { społeczności lokalnych } \\
\text { - Stworzenie wizerunku międzynarodowego lidera poprzez udział } \\
\text { w krajowych i międzynarodowych inicjatywach }\end{array}$ \\
\hline $\begin{array}{l}\text { Wypracowanie } \\
\text { i utrzymanie pozycji } \\
\text { odpowiedzialnego } \\
\text { pracodawcy }\end{array}$ & $\begin{array}{l}\text { - Prowadzenie działalności na podstawie najwyższych standardów } \\
\text { dialogu z pracownikami } \\
\text { - Stworzenie wizerunku odpowiedzialnego pracodawcy } \\
\text { - Osiągnięcie pozycji lidera w branży pod względem ochrony } \\
\text { zdrowia i bezpieczeństwa pracy, jak również stabilności } \\
\text { zatrudnienia i wynagrodzeń } \\
\text { - Promowanie transparentności z wykorzystaniem zasad etyki i ładu } \\
\text { korporacyjnego, a w szczególności poszanowaniem praw człowieka }\end{array}$ \\
\hline $\begin{array}{l}\text { Budowa wizerunku spółki } \\
\text { przyjaznej środowisku }\end{array}$ & $\begin{array}{l}\text { - Wzmacnianie świadomości roli i aktywności KGHM w zakresie } \\
\text { ochrony środowiska przez promocję inicjatyw związanych } \\
\text { z ochroną środowiska oraz programów CSR (Program EKO- } \\
\text { Zdrowie i Program Promocji Zdrowia) } \\
\text { - Tworzenie programów i inicjatyw mających na celu minimalizację } \\
\text { wpływu na środowisko (emisja gazów cieplarnianych, efektywność } \\
\text { energetyczna, zarządzanie odpadami i rekultywacja terenów po } \\
\text { zamknięciu kopalń) }\end{array}$ \\
\hline
\end{tabular}

Źródło: [Strategia społecznej odpowiedzialności biznesu (CSR) KGHM... 2015, s. 8-12]. 
- przejrzystość działań - wszystkie procedury podejmowania decyzji w imieniu ludzi na forum międzynarodowym powinny być ogólnodostępne;

- równość - warunkiem zwiększenia stabilności i bezpieczeństwa na świecie jest zmniejszenie ubóstwa; przez równość należy wówczas rozumieć sprawiedliwy system redystrybucji dóbr i bogactwa między krajami oraz sprawiedliwe warunki uczestnictwa w wymianie międzynarodowej;

- subsydiarność - społeczności lokalne powinny mieć podstawowe znaczenie, przekazując niektóre obowiązki na wyższe poziomy (regionalny, krajowy i światowy);

- różnorodność - zaspokajanie potrzeb krajowej ludności powinno stać się priorytetem, a dopiero później należy się orientować na handel z zagranicą; kontakty z innymi krajami i społecznościami powinny wynikać z potrzeb wewnętrznych, a nie z odgórnie ustalonych umów; ponadto zdrowie i godne życie wymagają także poszanowania prawa do różnorodności kulturowej, biologicznej, społecznej i gospodarczej.

Większość tych postulatów KGHM bierze pod uwagę, albowiem realizacja społecznej odpowiedzialności biznesu opiera się na takich wartościach, jak: bezpieczeństwo, współdziałanie, zorientowanie na wyniki, odpowiedzialność i odwaga. Wartości te są podstawą wszystkich działań KGHM na globalnych rynkach, a także pomagają $\mathrm{w}$ scaleniu międzynarodowych zespołów między spółkami, oddziałami i kontynentami [Raport zintegrowany... 2015, s. 8].

W KGHM od zawsze istotne były takie wartości, jak bezpieczeństwo, współdziałanie czy odpowiedzialność. Spółka jest dzisiaj firmą globalną, silnie zorientowaną na wyniki i odważnie patrzącą w przyszłość. Wartości tworzą DNA organizacji, ułatwiają podejmowanie właściwych wyborów dziś i budowanie długofalowych strategii na przyszłość. Kluczowe dla KGHM wartości, które mogą wpływać na łagodzenie skutków globalizacji, to [http://www.kghm.com]:

- Ochrona życia i zdrowia współpracowników, dbanie o środowisko naturalne i dobro najbliższych sąsiadów, realizowanie zrównoważonego rozwoju, co gwarantuje bezpieczeństwo rodzin pracowników, społeczności lokalnych, a także pozostałych interesariuszy spółki.

- Praca zespołów ludzi, ich doświadczenie, umiejętność dzielenia się wiedzą, które pozwalają osiągać zamierzone cele, rozwijać firmę i z optymizmem patrzeć w przyszłość. To jednocześnie możliwość wzajemnego poznawania się, budowania silnych więzi z firmą oraz otwierania się na różne opinie i kultury.

- Umiejętność dostosowywania się do zachodzących zmian, nieustanne inwestycje w ludzi oraz zasoby.

- Budowanie zaufania do KGHM w otaczającym firmę środowisku przez działania odpowiedzialne społecznie. Spółka jednocześnie bierze pełną odpowiedzialność za swoją aktywność. Prowadzi także politykę dobrego sąsiada.

- Spółka jest otwarta na świat. Nie boi się krytyki oraz wewnętrznych dyskusji, ponieważ tylko one pozwalają firmie się rozwijać. 
KGHM, opierając się na wskazanych wartościach, wzmacnia pozycję stabilnego, rozwijającego się globalnego lidera, który deklaruje dbanie o dobro wspólne, realizując strategię działań społecznie odpowiedzialnych. Przejawia się to w podejmowaniu inicjatyw mogących się przyczyniać do globalizacji etycznej i sprawiedliwej. Spółka dokonała standaryzacji podejścia do CSR w skali globalnej. Powołała w tym celu międzynarodowy zespół ds. CSR, który działa na bazie wspólnych dla KGHM celów strategicznych, czego skutkiem jest stworzenie globalnych programów CSR. Egzemplifikacją jednego z nich jest realizacja polityki „zero szkód”. Bezpieczeństwo stanowi bowiem jedną z podstawowych wartości, obejmując ochronę zdrowia pracowników i społeczności lokalnych, tworzenie przyjaznego środowiska pracy i minimalizowanie potencjalnych zagrożeń oraz wpływu na środowisko. Dział Procesów Kopalni Robinson, składający się z sekcji konserwacji procesów, operacyjnej, laboratoriów oraz hałd, otrzymał certyfikat osiągnięć w zakresie bezpieczeństwa Administracji BHP Kopalni (MSHA) za rok 2014 od Departamentu Pracy Stanów Zjednoczonych. Ta prestiżowa nagroda została przyznana pracownikom Kopalni Robinson za zakończenie roku kalendarzowego bez jakichkolwiek urazów ciała wymagających interwencji medycznej. Zespół procesów przepracował kolejnych 313953 roboczogodzin bez zgłaszania urazów ciała. Poza tym, jako wyraz uznania dla coraz lepszych wyników w obszarze BHP, Chilijskie Stowarzyszenie ds. Bezpieczeństwa (ACHS) obniżyło kopalni Sierra Gorda składkę ubezpieczenia społecznego na lata 2016-2017. Ubezpieczenie to jest obowiązkowe dla wszystkich kopalń działających w Chile. Wysokość składki zależy od wielkości obiektu oraz liczby odnotowanych wypadków. Program poprawy bezpieczeństwa pracy w Polsce doprowadził zaś do obniżenia wskaźnika LTIFR (liczba wypadków na milion przepracowanych godzin), który w 2008 roku wynosił 20,20, w 2013 - roku 13,84, a w 2014 roku obniżył się do poziomu 10,35 [Raport zintegrowany... 2015, s. 90-93]. Świadczy to o poważnym traktowaniu kwestii bezpieczeństwa i stałym wdrażaniu mechanizmów prewencyjnych. Zwiększenie świadomości, poziomu zaufania i motywacji wszystkich pracowników do stosowania zasady „zero szkód” znakomicie wpisuje się $\mathrm{w}$ wizję bezpieczeństwa całej międzynarodowej grupy KGHM.

Ponadto w zakresie doskonalenia współpracy ze społecznościami lokalnymi stworzono procedury, których celem jest poznanie i zrozumienie potrzeb interesariuszy, a także reagowanie na ich obawy. Tego rodzaju działania doprowadziły do stworzenia międzynarodowego programu wolontariatu w KGHM. Przykładowo w 2015 roku pracownicy z Kanady, Stanów Zjednoczonych, Chile i Polski wzięli udział w pierwszej w historii globalnej inicjatywie wsparcia dla chorego syna pracownika polskiej kopalni „Polkowice - Sieroszowice”. Celem, który osiągnięto, było przejechanie łącznie 2000 kilometrów na rowerach stacjonarnych. Niezależnie od szerokości geograficznej wszystkich wolontariuszy łączy zatem wspólny cel: niesienie pomocy potrzebującym, co znalazło również odzwierciedlenie w świątecznych inicjatywach na zakończenie 2015 roku. W Kanadzie przyłączono się do akcji organi- 
zacji charytatywnej YWCA „Przygarnij rodzinę”. Wolontariusze przygotowali również paczki dla najbardziej potrzebujących mieszkańców, a w ramach misji ulicznej rozdawali żywność i ciepłe napoje. Natomiast w chilijskiej kopalni Franke załoga zebrała datki na rzecz kościoła, który codziennie zapewnia posiłki potrzebującym dzieciom, a pracownicy kopalni Carlotta w Arizonie w Stanach Zjednoczonych wsparli Armię Zbawienia, która zakupiła wigilijne produkty spożywcze i zabawki dla dzieci. Jeżeli zaś chodzi o Polskę, to wolontariusze po raz kolejny wspomogli „Szlachetną Paczkę", ogólnopolską inicjatywę pomocy osobom w trudnej sytuacji materialnej, a w oddziałach zorganizowano liczne kiermasze, z których dochód został przekazany na dziecięcy turnus rehabilitacyjny lub na Dom Samotnych Matek z Dziećmi [Waszkis 2016, s. 28-29].

Poza tym prowadzone są liczne inicjatywy mające na celu wzmacnianie wewnętrznej i zewnętrznej pozycji spółki jako odpowiedzialnego pracodawcy i budowanie pozycji lidera w obszarze bezpieczeństwa pracy, a także relacji z partnerami biznesowymi. Wszystko to odbywa się przy współudziale w budowaniu spółki przyjaznej środowisku. Inicjatywy w tym zakresie mają na celu zwiększenie skuteczności komunikacji dotyczącej tematów środowiskowych przez otwartość w relacjach z partnerami. Stworzono system zarządzania energią, pozwalający na redukcję jej zużycia i emisji gazów cieplarnianych, oraz plan rekultywacji terenów po zamykanych kopalniach [Strategia społecznej odpowiedzialności biznesu (CSR) KGHM... 2015, s. 7].

Należy także pamiętać o tym, iż globalizacja jeszcze przez długi czas będzie ewoluować, czego skutkiem może być zupełnie inny, mniej rozpoznawalny porządek świata [Banas 2002, s. 32]. Wobec tego rozwój organizacji pozarządowych i międzynarodowych, ruchów solidarnościowych oraz pojawienie się pewnych form zarządzania światowego, stanowi wychodzenie naprzeciwko równoważeniu dysproporcji w czasie oraz percepcji przestrzennych relacji pomiędzy narodami [Janeczek, Janeczek 2014, s. 185]. KGHM jest członkiem krajowych i międzynarodowych organizacji branżowych i specjalistycznych. Spółka jest aktywna także na forum organizacji zrzeszających pracodawców oraz propagujących ideę społecznej odpowiedzialności i zrównoważonego rozwoju (tab. 2) [Zintegrowany raport roczny.... 2014, s. 119].

Członkostwo KGHM w różnych organizacjach i stowarzyszeniach znajduje przełożenie na praktykę, przykładem czego jest dokument Strategia CSR KGHM na lata 2015-2020. Została ona opracowana na podstawie dziesięciu zasad Global Compact, czyli inicjatywy ONZ poświęconej realizacji misji CSR w ujęciu globalnym. Spełnia przy tym wytyczne Międzynarodowej Rady ds. Górnictwa i Metali, a także wytyczne Światowej Inicjatywy Sprawozdawczej (G4) dotyczącej sprawozdawczości w zakresie zrównoważonego rozwoju. Wartym uwagi jest również dołączeniem KGHM International do Stowarzyszenia MAC (Mining Association of Canada) w 2013 roku, które dąży do zwiększenia reputacji przemysłu wydobywczego, odgrywającego niezwykle odpowiedzialną rolę, rozpowszechniania działań na rzecz 
Tabela 3. Członkostwo KGHM w wybranych organizacjach

\begin{tabular}{|c|c|}
\hline \multicolumn{2}{|r|}{ Organizacje branżowe } \\
\hline $\begin{array}{l}\text { European Copper } \\
\text { Institute (ECI) }\end{array}$ & $\begin{array}{l}\text { Jednostka reprezentująca sektor wydobycia i produkcji miedzi, zajmująca się } \\
\text { m.in. promowaniem technologii związanych z użyciem miedzi, działaniami na rzecz } \\
\text { środowiska i ludzkiego zdrowia czy wypracowywaniem standardów branżowych na } \\
\text { poziomie zarówno poszczególnych krajów, jak i Unii Europejskiej }\end{array}$ \\
\hline $\begin{array}{l}\text { International Copper } \\
\text { Study Group (ICSG) }\end{array}$ & $\begin{array}{l}\text { Międzyrządowe forum, którego zadaniem jest zwiększenie transparentności rynku } \\
\text { miedzi oraz promowanie współpracy i dialogu w tym sektorze }\end{array}$ \\
\hline $\begin{array}{l}\text { International Precious } \\
\text { Metals Institute (IPMI) }\end{array}$ & $\begin{array}{l}\text { Największa i najbardziej znana organizacja zrzeszająca producentów, przetwórców, } \\
\text { naukowców, instytucje finansowe i kupców związanych z metalami szlachetnymi. } \\
\text { Misją IPMI jest promowanie efektywnego i racjonalnego wykorzystywania tych } \\
\text { surowców }\end{array}$ \\
\hline \multicolumn{2}{|r|}{ Organizacje propagujące idee społecznej odpowiedzialności biznesu } \\
\hline $\begin{array}{l}\text { Forum Odpowiedzialnego } \\
\text { Biznesu (FOB) }\end{array}$ & $\begin{array}{l}\text { KGHM jest partnerem strategicznym organizacji od } 2012 \text { roku. Misją FOB jest } \\
\text { upowszechnianie idei odpowiedzialnego biznesu jako standardu obowiązującego } \\
\text { w Polsce w celu zwiększenia konkurencyjności przedsiębiorstw, zadowolenia } \\
\text { społecznego i poprawy stanu środowiska }\end{array}$ \\
\hline $\begin{array}{l}\text { Koalicja Prezesi- } \\
\text { Wolontariusze } 2011\end{array}$ & $\begin{array}{l}\text { Organizacja zrzeszająca liderów biznesu, którzy udzielają się społecznie. } \\
\text { Stowarzyszenie stanowi platformę wymiany doświadczeń i dobrych praktyk } \\
\text { z zakresu wolontariatu }\end{array}$ \\
\hline Koalicja CSR & $\begin{array}{l}\text { Inicjatywa Pracodawców RP. Głównym celem projektu skupiającego największe } \\
\text { polskie firmy jest pomoc we wdrażaniu przez przedsiębiorców zasad społecznej } \\
\text { odpowiedzialności biznesu }\end{array}$ \\
\hline \multicolumn{2}{|r|}{ Organizacje specjalistyczne } \\
\hline $\begin{array}{l}\text { European Sulphuric Acid } \\
\text { Association (CEFIC - } \\
\text { ESA) }\end{array}$ & $\begin{array}{l}\text { Organizacja zrzeszająca interesariuszy związanych z produkcją, dystrybucją, } \\
\text { przetwarzaniem i transportem kwasu siarkowego }\end{array}$ \\
\hline $\begin{array}{l}\text { Central Europe Energy } \\
\text { Partners }\end{array}$ & $\begin{array}{l}\text { Międzynarodowa organizacja reprezentująca szeroko rozumiany sektor energii } \\
\text { z Europy Centralnej (ropa, gaz ziemny, węgiel, energia elektryczna, odnawialne } \\
\text { źródła energii, energia jądrowa, interkonektory) }\end{array}$ \\
\hline $\begin{array}{l}\text { Stowarzyszenie } \\
\text { Księgowych w Polsce }\end{array}$ & $\begin{array}{l}\text { Stowarzyszenie zrzesza przedstawicieli środowiska związanego z rachunkowością } \\
\text { i finansami. Jego misją jest rozwój standardów polskiej branży }\end{array}$ \\
\hline $\begin{array}{l}\text { Stowarzyszenie } \\
\text { Emitentów Giełdowych }\end{array}$ & $\begin{array}{l}\text { Stowarzyszenie, jako reprezentant spółek notowanych na Giełdzie Papierów } \\
\text { Wartościowych, służy środowisku emitentów wiedzą doradztwem w zakresie } \\
\text { regulacji rynku giełdowego oraz praw i powinności uczestniczących w nim spółek }\end{array}$ \\
\hline Polska Izba Ekologii & $\begin{array}{l}\text { Stowarzyszenie zrzesza ponad } 100 \text { przedsiębiorstw, biur projektowych i instytutów } \\
\text { badawczych. Celem organizacji jest poprawa stanu środowiska naturalnego w kraju } \\
\text { oraz kreowanie świadomości ekologicznej Polaków }\end{array}$ \\
\hline \multicolumn{2}{|r|}{ Organizacje biznesowe } \\
\hline $\begin{array}{l}\text { Związek Pracodawców } \\
\text { Polska Miedź }\end{array}$ & $\begin{array}{l}\text { Założony przez KGHM Związek zrzesza ponad } 100 \text { podmiotów z Dolnego Śląska. } \\
\text { Organizacja zajmuje się monitorowaniem i opiniowaniem projektów aktów } \\
\text { prawnych, prowadzeniem szkoleń oraz realizacją inicjatyw służących rozwojowi } \\
\text { przedsiębiorczości }\end{array}$ \\
\hline $\begin{array}{l}\text { Zachodnia Izba } \\
\text { Gospodarcza }\end{array}$ & $\begin{array}{l}\text { Organizacja samorządowa, której celem jest m.in. wspieranie rozwoju } \\
\text { przedsiębiorczości oraz upowszechnianie zasad etyki w działalności gospodarczej. } \\
\text { Zrzesza ponad } 300 \text { firm z całego regionu }\end{array}$ \\
\hline $\begin{array}{l}\text { Izba Gospodarcza Metali } \\
\text { Nieżelaznych } \\
\text { i Recyklingu }\end{array}$ & $\begin{array}{l}\text { Izba reprezentuje polskie przedsiębiorstwa z sektora metali niezależnych } \\
\text { w relacjach z krajowymi oraz międzynarodowymi agendami administracji szczebla } \\
\text { samorządowego i krajowego w Polsce oraz wobec instytucji Unii Europejskiej }\end{array}$ \\
\hline
\end{tabular}

Źródło: [Zintegrowany raport roczny... 2014, s. 119-120]. 
zrównoważonego rozwoju wśród funkcjonujących na rynku firm. W tym celu Stowarzyszenie MAC wprowadziło program „Inicjatywa na rzecz Zrównoważonego Wydobycia (TSM)", który obejmuje plany ramowe, narzędzia, wytyczne oraz wskaźniki efektywności. Program ma pozwolić poradzić sobie z kluczowym ryzykiem występującym w przemyśle wydobywczym, zapobiegając tym samym potencjalnej szkodzie wyrządzanej pracownikom, społecznościom lokalnym czy środowisku. Na tej podstawie KGHM International opracowało tabelę wskazującą założenia programu, a także poszczególne role i obowiązki pozwalające na jego udane wdrożenie. Do każdego obszaru efektywności przypisano lidera protokołu, który współpracując z interesariuszami zewnętrznymi i wewnętrznymi uzupełnia luki i opracowuje konkretne programy i systemy formalne [Jung 2015]. Inicjatywa TSM może się przyczynić do zdobycia wiedzy i wdrażania najlepszych praktyk w branży, a także pozwolić na czynny udział zarówno w opracowaniu nowych i rozwoju dotychczasowych ram i regulacji.

Na zakończenie należy wskazać, że KGHM, podejmując działania społecznie odpowiedzialne jako przedsiębiorstwo międzynarodowe, może zwrócić uwagę na strategie realizacji postulatu etycznej, solidarnej i zhumanizowanej globalizacji, które można odnaleźć w literaturze przedmiotu. Jedna z nich odnosi się do globalnej redystrybucji, mogącej przybrać postać dobrowolnego działania charytatywnego albo wymuszonego programu oddłużeniowego. Kolejna ma charakter polityki generalnej, czyli działań nad ustanowieniem obowiązujących w skali światowej reguł ładu gospodarczego, które spowodowałyby, że niemoralne zachowania będą nieopłacalne. Ostatni element strategii może mieć istotne znaczenie dla działalności KGHM, ponieważ pokazuje pozytywny wpływ działań społecznie odpowiedzialnych na konkurencyjność [Dylus 2005, s. 141-151].

Ponadto należy na bieżąco analizować proces formułowania i implementacji strategii CSR KGHM, często bowiem korporacje międzynarodowe prowadzą grę polegającą na rzeczywistym ograniczaniu działań społecznie odpowiedzialnych do reputacji spółki i braku istotnych gwarancji, że obietnice zawarte w ich strategii CSR znajdą odbicie w konkretnych działaniach. W realizacji tej koncepcji ważną rolę odgrywają także, relacje społeczne koordynowane przez specjalnie powołaną komórkę organizacyjną. Obecnie Skarb Państwa posiada 31,79\% (tj. 63589 900) akcji spółki. Pozostała część jest w rękach polskich i zagranicznych akcjonariuszy indywidualnych i instytucjonalnych, tworząc tzw. free float. Związane są z tym częste zmiany personalne na różnych szczeblach w spółce, będące efektem wyborów parlamentarnych, co wpływa na zmianę poglądów i koncepcji działań z zakresu CSR.

Przed KGHM stoi także wyzwanie związane z koniecznością integrowania działań społecznych na trzech kontynentach ze strategią biznesową zgodnie z przekonaniem, że każda firma powinna traktować zagadnienia związane z CSR w kontekście swojej strategii, specyfiki oraz warunków, w jakich działa [Cowe 2004, s. 8]. Strategia stanowi zatem ogniwo łączące firmę z rynkiem i środowiskiem pozarynkowym, w którym dochodzi do dynamicznych interakcji z różnymi grupami interesariuszy. 
KGHM, włączając CSR do swojej długofalowej strategii, może zatem doprowadzić do podporządkowania tego obszaru celom firmy, a nie potrzebom interesariuszy. Ponadto zintegrowanie wartości i oczekiwań interesariuszy na trzech kontynentach z działalnością biznesową stanowi największe wyzwanie dla spółki. Całej grupie KGHM może być trudno zaspokajać różne potrzeby społeczności lokalnych, co może powodować rozluźnianie związków z którymś regionem.

\section{Zakończenie}

Koncepcja społecznej odpowiedzialności przedsiębiorstw coraz bardziej zyskuje na znaczeniu, czego przykładem są działania podejmowane przez KGHM. Spowodowane jest to determinowaniem warunków działania przedsiębiorstwa przez zmieniające się otoczenie oraz globalny charakter działalności.

Skutki popularyzacji społecznej odpowiedzialności przedsiębiorstw nie ograniczają się jedynie do ekonomicznych aspektów ich funkcjonowania. Mają także znaczenie podczas realizacji postulatów zmiany aktualnego modelu globalizacji, którego charakter jest ściśle związany z działalnością przedsiębiorstw międzynarodowych, do których należy np. KGHM. Społeczna odpowiedzialność otwiera zatem możliwość postulowanej humanizacji procesu globalizacji [Nakonieczna 2008, s. 181]. Jednakże należy zauważyć, iż koncepcja CSR nie daje gotowych rozwiązań w zakresie międzynarodowej działalności spółki. Liczba wpływających na nią czynników jest ogromna, a ich zmienność jest dynamiczna. Jednak obowiązki, jakie KGHM ma w tym względzie, wymagają świadomości, wiedzy i przekonania o konieczności bycia odpowiedzialnym uczestnikiem rynku. Zrozumienie odmienności może się przyczynić do większej harmonii w budowaniu przez spółkę relacji z partnerami zagranicznymi. Ponadto dla kształtowania wrażliwości etycznej w obliczu współczesnych dylematów moralnych pojawiających się przed menedżerami konieczne jest podejście interdyscyplinarne, wymagające współpracy różnych dyscyplin naukowych pod kątem zakorzenionych w nich zagadnień etycznych. Otwarcie kolejnych dziedzin wiedzy na problem odpowiedzialności społecznej oznacza dla przedsiębiorstw nową motywację do działań na rzecz tej idei [Janeczek, Janeczek 2014, s. 189].

\section{Literatura}

Adamczyk J., 2009, Społeczna odpowiedzialność przedsiębiorstw. Teoria i praktyka, Polskie Wydawnictwo Ekonomiczne, Warszawa.

Banas S., 2002, Globalizacja, jej dotychczasowe skutki i prognozowany dalszy rozwój, [w:] Internacjonalizacja i globalizacja przedsiębiorstwa i gospodarki, Rymarczyk J., Michalczyk W. (red.), Wydawnictwo Akademii Ekonomicznej, Wrocław.

Borkowski R., 2003, Globalizacja, cywilizacja, ponowoczesność, [w:] Glopalopolis. Kosmiczna wioska. Szanse i zagrożenia, Borkowski R. (red.), Instytut Wydawniczy PAX, Inco Veritas, Warszawa. 
Borowicz J., 1997, Ewolucja przedsiębiorstw - od strategii międzynarodowej do strategii globalnej, [w:] Bariery internacjonalizacji przedsiębiorstwa, Nowakowski M.K. (red.), Key Text, Warszawa. Brilman J., 2002, Nowoczesne koncepcje i metody zarzadzania, PWE, Warszawa.

Copeland P.T., Koller T., Murrin J., 1997, Wycena, mierzenie i ksztattowanie wartości firm, WIG Press, Warszawa.

Cowe R., 2004, CSR Hits the Boardroom, [w:] EBF on Corporate Social Responsibility, European Business Forum, London.

Człowiek wśród żywiołów, 2014, KGHM Polska Miedź SA, Lubin.

Dylus A., 2005, Globalizacja. Refleksje etyczne, Ossolineum, Wrocław.

Giddens A., 2000, Runaway World. How Globalization is Reshaping Our Lives, Routledge, New York. Haliżak E., 2006, Procesy globalizacji a stosunki międzynarodowe, [w:] Stosunki międzynarodowe. Geneza, struktura, dynamika, Haliżak E., Kuźniar R. (red.), Wydawnictwo Uniwersytetu Warszawskiego, Warszawa.

Held D., McGrew A., 2001, Globalization, [w:] The Oxford Companion to Politics of the World, Krieger J. (red.), Oxford University Press, Oxford.

http://www.kghm.com (7.02.2016).

Janeczek U., Janeczek Z., 2014, Koncepcja społecznej odpowiedzialności a proces internacjonalizacji i globalizacji, [w:] Społeczna odpowiedzialność w przestrzeni publicznej. Strategie i społeczne znaczenie, Kapias M. (red.), Wydawnictwo Naukowe „Śląsk” Sp. z o.o., Katowice.

Jan Paweł II, 2001, Globalizacja a etyka, przemówienie do uczestników VII Sesji Plenarnej Papieskiej Akademii Nauk Spolecznych, 27 kwietnia.

Jung Ch., 2015, Inicjatywa na rzecz Zrównoważonego Wydobycia (TSM), Portal KGHM International, Vancouver.

Klimczak B., 2008, Między ekonomia a etyka, Wydawnictwo Uniwersytetu Ekonomicznego we Wrocławiu, Wrocław.

Kocoń P., 2014, Odpowiedzialna organizacja, [w:] Społeczna odpowiedzialność w przestrzeni publicznej. Strategie i społeczne znaczenie, Kapias M. (red.), Wydawnictwo Naukowe „Śląsk” Sp. z o.o., Katowice.

Krukowska M., 2012, Jak oceniać odpowiedzialność społeczna biznesu?, Wydawnictwo Naukowe SCRIPTORIUM, Opole.

Kuźmińska A., Sawicki J., 2009, Globalizacja - nowy kształt porządku światowego, [w:] Procesy globalizacji, Rymarczyk J., Skulska B., Michalczyk M. (red.), Wydawnictwo Uniwersytetu Ekonomicznego we Wrocławiu, Wrocław.

Mendel T., 2002, Partycypacja w zarządzaniu wspótczesnymi organizacjami, Wydawnictwo Akademii Ekonomicznej w Poznaniu, Poznań.

Micał M., 2008, Proces globalizacji we wspótczesnym świecie, Zeszyty Naukowe Zakładu Europeistyki Wyższej Szkoły Informatyki i Zarządzania w Rzeszowie, nr 3(8).

Mojsiewicz Cz., 2003, Rozwój procesów o charakterze globalnym, [w:] Prawo, instytucje i polityka $w$ procesie globalizacji, Haliżak E., Kuźniar R. (red.), Księga jubileuszowa dedykowana prof. J. Symonidesowi, Warszawa.

Nakonieczna J., 2005, ,Inny świat jest możliwy” - porządek międzynarodowy w myśli krytyków globalizacji, [w:] Porządek międzynarodowy u progu XXI wieku, Kuźniar R. (red.), Wydawnictwo Uniwersytetu Warszawskiego, Warszawa.

Nakonieczna J., 2008, Społeczna odpowiedzialność przedsiębiorstw międzynarodowych, Difin, Warszawa.

Raport zintegrowany KGHM Polska Miedź SA za rok 2014, 2015, Lubin.

Rok B., 2013, Społeczna odpowiedzialność biznesu, [w:] Biznes, etyka, odpowiedzialność. Podręcznik akademicki, Gasparski W. (red.), Wydawnictwo Profesjonalne PWN, Warszawa. 
Rybak M., 2011, Etyka menedżera - społeczna odpowiedzialność przedsiębiorstwa, PWN, Warszawa. Rymarczyk R., 2012, Biznes międzynarodowy, Polskie Wydawnictwo Ekonomiczne, Warszawa.

Sojak J., 2002, Oświadczenia EBEN w promowaniu etycznego biznesu, [w:] Etyka biznesu w zastosowaniach praktycznych - inicjatywy, programy, kodeksy, Gasparski W., Lewicka-Strzałecka A., Rok B., Szulczewski G. (red.), Warszawa.

Strategia KGHM Polska Miedź SA na lata 2015-2020 z perspektywą do 2040 roku, 2015, Lubin.

Strategia społecznej odpowiedzialności biznesu (CSR) KGHM na lata 2015-2020, 2015, Lubin.

Waszkis M., 2016, Trzy kontynenty, jeden wolontariat, Focus KGHM, nr 1 (7), s. 28-29.

Zintegrowany raport roczny 2013 KGHM Polska Miedź SA, 2014, Lubin. 